\title{
Something We're Not: John Brannon, Negative Approach, and the Ruins of Detroit
}

\author{
STEPHEN CEDARS
}

\begin{abstract}
This paper considers the musical output of Detroit-based hardcore punk band Negative Approach (and particularly its vocalist John Brannon), as a lens through which to understand Detroit's place in what Andreas Huyssen calls the "imaginary of ruins." During their short existence from 1981-1984, Negative Approach developed a sound that is frequently understood to reflect Detroit, the band's intensity and Brannon's vicious vocal timbre correlated with the image of a city 'ruined' by the economic decline and racial inequities hastened by its infamous 1967 riots. Drawing on ruin studies, a history of Detroit, the context of American hardcore rock, and on the timbral and structural qualities of Brannon's music, the paper considers both the usefulness and problematic limitations of using ruin imagery to understand a surviving city, of reducing its material reality solely to metonymic expression of post-Fordist decline. While the paper does elucidate the correlation between Brannon's music and the city's struggles — which include a strained relationship with its wealthier, de facto segregated suburbs-it also illustrates the extent to which such designations are inherently problematic both for flattening the music's affect and for overlooking the material reality of a city and its citizens, who struggle onwards with dignity and imagination rather than defining themselves solely in reference to their challenges.
\end{abstract}

\section{Ian [MacKaye] was just freaking out saying, "This is fucked up man, this is crazy," and I was just like "Welcome to Detroit!" \\ -John Brannon, vocalist and songwriter, Negative Approach}

In June of 1982, Detroit's Freezer Theater went out with a hell of a show. The night began with what those in the scene consider "one of the greatest shows for Detroit hardcore"1 - the city's own "violent breed of eardrum shredders," ${ }^{2}$ Negative Approach, opening for out-of-town hardcore luminaries Minor Threatand ended with a riot "that resembled a battle from the middle ages." ${ }^{3}$ A casual observer might have been unsurprised; the Freezer, itself "such a fucking hole that it made CBGB's look like a palace,"4 was located in Detroit's Cass Corridor, a notoriously decrepit, neglected neighborhood, or more colorfully, "the land that time forgot," in the eyes of the young men playing music there. ${ }^{5}$ Furthermore, it was in Detroit, a city that by 1982 was already being mythologized as what the New York Times would later call "America's first thirdworld city."

Yet the Freezer Theater was also, for the bands that played there, a site of ambitious self-expression, its depravity not a burden to be mitigated but in fact the very condition that made their particular brand of hardcore rebellion possible. It was a site both creative and destructive, where the riot referenced in the

${ }^{1}$ John Brannon, quoted in Tony Rettman, Why Be Something That You're Not (Huntington Beach, CA: Revelation Records, 2010), 113.

2 John Griffin, “Tied Down-Negative Approach,” All Music Guide.

${ }^{3}$ Ian MacKaye, quoted in Rettman, Why Be Something, 114.

${ }^{4}$ Brian Hyland, quoted in ibid., 94.

${ }^{5}$ Taken from ibid., 85.

${ }^{6}$ Ze'ev Chafets, "The Tragedy of Detroit," The New York Times, July 29, 1990. 
epigraph could also signify solidarity, an ambivalent celebration of community built around music that functioned as an "undeniable steel toe to the face." For the musicians from Detroit, most notably Negative Approach (hereafter cited in text as NA) vocalist John Brannon, known for his "ferocious, unrelenting, highly emotional, ... pulverizing" vocal style, ${ }^{8}$ the creative and destructive were intertwined not only in hardcore's "adrenalized" aesthetic, ${ }^{9}$ but also in the material reality of their city. Minor Threat's Ian MacKaye panicked when violence spilled outside the music and into the streets; Brannon and his boys took it in stride.

That reading, at least, would explain why rock critics often understand NA's "stripped down and mean" sound as one "that could have only come from Detroit."10 Of course, such a correlation says less about a hardcore punk band than it does about the U.S. American, if not world, conception of the city. In the public imaginary, Detroit has steadily "[descended] into a deindustrialized wasteland" since its infamous 1967 race riots, ${ }^{11}$ offering fertile if tragic insight for ruin studies, cultural theoreticians, and sociologists, among others. That the riots might better be termed an uprising, or that they continue to serve as a smokescreen shielding the even more pernicious influences of social and racial inequality that had afflicted the city for decades before 1967, only reinforces why the city has such enduring appeal for empathetic ally and voyeuristic ruingazer alike.

Indeed, I aim here to attempt my own consideration of Detroit in relation to what Andreas Huyssen calls the "imaginary of ruins," ${ }^{12}$ specifically through the lens of NA and John Brannon. I want to consider Detroit as both metaphor and material city, as a site of both actual rubble and "aestheticized" symbolic ruin. ${ }^{13}$ As metonym for the nation's (if not world's) tumultuous relationship with race, capitalism, and the social contract, Detroit undoubtedly offers a "seductive power" to engage the cultural "anxiety [over] decline"; $;^{14}$ yet, as Gastón Gordillo reminds us, understanding any place as metaphoric ruin makes of it "an abstraction about the past" contingent on our "affective distancing and bodily estrangement." 15 Such nostalgic distance risks not only flattening complex, nuanced understanding, but also discounting the daily, all-too-material struggles of people who lived and continue to live in those places.

By telling the story of John Brannon, Negative Approach, and the early 1980s Cass Corridor hardcore scene, I intend to tell a story of such struggles. The story I tell is a historical one, but presumes no insight into the conscious intentions of the artists involved; instead, I read the era from the present, understanding the hardcore scene's achievements as offering a distinct lens towards characterizing their city and its place in the U.S. discourse. As I will tell it, the story is about young men whose work embraced ambivalence and refused to engage a simple binary of ruins (i.e., creation vs. destruction), thereby constructing a site that neither ignored the reality of Detroit and the nation's decline, nor accepted that reality as deterministic endpoint. On one hand, the intense aural assault of NA's music offers both reflection of and comment on an American ruin, not merely a ruined city but also the greater ruin of 1960 s political efficacy, that "Great

\footnotetext{
${ }^{7}$ Matt Kantor, “Artist Biography of Negative Approach,” All Music Guide, https://www.allmusic.com/artist/negativeapproach-mn0000386253/biography.

${ }^{8}$ Brett Callwood, “Three Chords \& the Truth," Detroit Metro Times, June 9, 2010.

${ }^{9}$ Michael Azerrad, Our Band Could Be Your Life (New York: Little, Brown, and Co., 2002), 119.

${ }^{10}$ Matt Kantor, “Total Recall-Negative Approach,” All Music Guide, https:/www.allmusic.com/album/total-recallmw0000086382.

${ }^{11}$ Dora Ape, Beautiful Terrible Ruins: Detroit and the Anxiety of Decline (Ithaca, NY: Rutgers University Press, 2019$), 157$.

${ }^{12}$ Andreas Huyssen, “Nostalgia for Ruins," Grey Room 23 (2006), 20, https://doi.org/10.1162/grey.2006.1.23.6.

${ }^{13}$ Ibid., 8.

${ }^{14}$ Dora Apel, Beautiful Terrible Ruins (Ithaca, NY: Rutgers University Press, 2019), 58, 9-10, https://doi.org/10.36019/9780813574097-toc.

${ }^{15}$ Gastón R. Gordillo, Rubble: The Afterlife of Destruction (Durham: Duke University Press, 2014), 5, https://doi.org/10.2307/i.ctv11316w0.
} 
Society" promise of equity and equality and empathy, a ruin of the American Dream, more or less. And yet on the other hand, Brannon's story is also one of vivacity, of an aesthetic efficacy born from those ruins, efficacy not to rebuild but to reclaim, the story of an aesthetic productively creative through its performative embrace of negativity. By telling this band's story as one of synergy between cultural/political disaffection and committed, idiosyncratic, artistic revolt, I intend also to highlight how the U.S. American preoccupation with Detroit as a ruin of political activism and optimism can be both elucidating and dangerously, deterministically myopic.

\section{Welcome to Detroit!}

Looking back to the epigraph: one might read in Brannon's dismissal of MacKaye's concern"Welcome to Detroit!"- a gleeful anarchism, imagining Brannon at twenty years old, his head shaved, his eyes "bulged out of their sockets," 16 smiling like Nero, untouched by the chaos around him. Such a harsh dichotomy — disinterested nihilism against exuberant celebration—offers a means of understanding both the serious social, racial, and economic issues that facilitated Detroit's decline, and the contemporary American framing of it in almost mythic terms. Brannon likely did not mean to callously suggest that he and his city were inherently vicious or animalistic - in truth, the riot outside the Freezer was no rehash of 1967, but rather was largely carried out between folks who knew and regularly partied with one another ${ }^{17}$ — but instead probably meant to reference the expectation of Detroit as a city that had been defined in terms of violence from both within and without. In this way, regardless of Brannon's intent, the statement has a political overtone: we cannot quite understand the sentiment outside of the deeply political landscape of post-riot Detroit.

As the story usually goes, Detroit was a wellspring of promise at the time of the 1967 riots. It was the birthplace of U.S. innovation in the guise of Henry Ford, home to the "Big Three" automakers (Ford, Chrysler, and General Motors), the "very essence of American industry," a place supposedly offering jobs and good middle class lives to everybody, most notably to the Black Americans who fled the South in the Second Great Migration. ${ }^{18}$ There were strong unions and vigorous civil rights activism that worked in symbiosis with the robust capitalist expansion that made it all possible, ensuring the city's centrality for a nation at its own "peak of economic and global strength." ${ }^{19}$ In the imaginary at least, Detroit was a beacon of post-war potential, where the profit motive and political protections worked hand in hand to ensure prosperity and equality for any willing to do their part, evidence of an enduring, equitable Social Contract.

That story takes an unfortunate turn on July 23, 1967, when the police raided an illegal after-hours speakeasy in one of Detroit's largest Black neighborhoods. Community pushback to police overreach escalated over five days into forty-three casualties, thousands of arrests, and property damage in excess of $\$ 36$ million by the time that the National Guard left town. ${ }^{20}$ In the wake of that unrest followed a steady exodus: industrial relocation alongside "White flight" into Detroit's copious suburbs, all of which significantly diminished the city's prosperity. By 2013, the year the city's government declared bankruptcy,

\footnotetext{
${ }^{16}$ Griffin, “Tied Down-Negative Approach.”

${ }^{17}$ Roberta Mock, “'This ain't no love-in, this ain't no happenin': Misfits, Detroit hardcore and the performance of zombie scenarios," Studies in Theatre and Performance 34, no. 3 (2014), 207, https://doi.org/10.1080/14682761.2014.961363.

${ }^{18}$ Thomas J. Sugrue, The Origins of the Urban Crisis: Race and Inequality in Postwar Detroit (Princeton, NJ: Princeton University Press, 1996), 17.

${ }^{19}$ David Maraniss, Once in a Great City: A Detroit Story (New York: Simon \& Schuster, 2015), 355, Sugrue, Origins, $189,13,6$.

${ }^{20}$ Sugrue, Origins, 259.
} 
Detroit's population had dropped 50\% from its 1950 height, ${ }^{21}$ and the expanse of abandoned property"over ten thousand houses are uninhabited; over sixty thousand lots lie empty, marring almost every city neighborhood"-marks much of the city as "eerily apocalyptic." 22 Detroit became a ruin.

The obvious simplicity of such a positivist historical narrative has nevertheless not discouraged a "mythmaking" discourse that frames the riots as "foundational to the ensuing decline of Detroit," 23 if not metonymic articulation of so many still-controversial issues: race, labor, income inequality, the welfare state, and so on. For conservatives, the tragedy is one of law and order: an African American population acted against its self-interest through "irrational, irresponsible" behavior in $1967,{ }^{24}$ then refused to suitably address the intensifying violent crime that followed over the next four decades. ${ }^{25}$ The 1974 election of Black mayor Coleman Young was supposed to bring equity but instead was perceived as a divisive hastening of the city's decline, unable to counteract the crime epidemic that continued to push industry away. ${ }^{26}$ The city, in this narrative, was already too far gone.

The conventional liberal narrative is perhaps more nuanced but nevertheless equally positivist in its insistence that the city's deterioration resulted from neoliberal inequities that were operating even in the supposed halcyon days. Federal pro-business incentives encouraged corporate disinvestment (and subsequent unemployment) as early as the $1950 \mathrm{~s},{ }^{27}$ and the pretense of racial equality during that period is deeply belied by the frequent, sometimes violent housing discrimination directed against Black homeowners both in the city and in the suburbs, which were enjoying the benefits of "White flight" well before the riots. ${ }^{28}$ In this narrative, the systemic rot predated the riots, which then ought be more appropriately termed what Mark Jay and Philip Conklin call "the Great Rebellion," ${ }^{29}$ more protest or uprising than mayhem. Either way, it did not work. Coleman Young was, in this narrative, too easy on corporate interests and too callous towards the struggling Black underclass. ${ }^{30} \mathrm{He}$ could not control the already persistent systemic inequities, which left 1980s Detroit—the milieu from which the hardcore scene was born-as "the country's murder capital." ${ }^{31}$

Despite their marked differences, these readings of post-riot Detroit nevertheless share a determinist sensibility, one which understands the city in "mythic terms, as winner/loser, moral/immoral," 32 as a ruin brought on by tragic inevitabilities. In the same way that the "earlier imagination" of the nineteenth-century Romantics "fastened on to the ruins of classical antiquity" as articulation for their "fear and obsession with the passage of time" and their "nightmare . . that all history might ultimately be overwhelmed by nature," 33 contemporary society sees in Detroit's blighted neighborhoods "the iconic ruin forms" that imbue social forces (poverty, discrimination, globalization, etc.) with similarly tragic intensity. ${ }^{34}$ Whether those tragic

${ }^{21}$ Apel, Beautiful Terrible Ruins, 54.

${ }^{22}$ Sugrue, Origins, 3.

${ }^{23}$ Mark Jay and Philip Conklin, A People's History of Detroit (Durham: Duke University Press, 2020), 129-30, https://doi.org/10.1215/9781478009351.

${ }^{24}$ Jay and Conklin, A People's History, 129-30.

${ }^{25}$ Apel, Beautiful Terrible Ruins, 154.

${ }^{26}$ Jay and Conklin, A People's History, 195-8.

${ }^{27}$ Sugrue, Origins, 147.

${ }^{28}$ Ibid., 34, 193, 266.

${ }^{29}$ Jay and Conklin, A People's History.

${ }^{30}$ Ibid., 196-7.

${ }^{31}$ Ibid., 208.

${ }^{32}$ Ibid., 129-30.

${ }^{33}$ Huyssen, "Nostalgia for Ruins," 11, 13.

${ }^{34}$ Apel, Beautiful Terrible Ruins, 6. 
forces are identified as racism, neoliberalism, or the decline of traditional values, they are to the public political discourse nevertheless as much forces of "nature" and "time" as they are material realities. ${ }^{35}$ That the city survives in the public imaginary largely as a discourse rather than as a site, as metonym rather than material location, is itself a tragedy of a different sort. In the rubble of Detroit, then, we might read not just the ruins of a once-promising city, but also the ruins of a political optimism, one that was supposedly capable of embracing divergent perspectives in the ultimate faith that justice will win in the end.

\section{The Ruins of Detroit}

I get to travel a lot, but Detroit's home. I'll always come back to it. I don't give a fuck what anyone else has to say. There's nowhere else I want to live. ${ }^{36}$

\section{-John Brannon}

The temptation to read Negative Approach as a pessimistic reflection of a ruined Detroit (and itself reflection of a decayed American Dream) is easy to indulge. As the "undisputed champs of Midwestern hardcore" ${ }^{37}$ - a reputation built in no small part on Brannon being several years older than most of the other musicians who played in the scene (many of whom were still in high school), and on his actually living in the Cass Corridor neighborhood himself-NA and its legacy have come to represent the scene, sometimes even to the neglect of the rest of the bands who played there. ${ }^{38}$ Given their centrality both at the time and in the conventional narrative of the period, I will in my argument consider them as an emblematic expression of the correlation between the ruined city and the brutality of the hardcore aesthetic that they may have perfected but were hardly alone in practicing. The story I tell is both retrospective-I can only necessarily speak from my present vantage, so will "read" the band and its contemporaries rather than attempt to uncover their understandings from the time-and limited: that I, too, focus on NA at the expense of other Detroit bands that could be framed in these or similar terms is largely a matter of scope, and I hope the deficit might serve as inspiration for more of this music to be analyzed in the academic literature.

One need not be incredibly imaginative to hear corollaries to the rubble of Cass Corridor in the sound of Negative Approach. Playing primarily for "the little nihilist kids" 39 in a neighborhood so "left for dead by the local government" ${ }^{\text {" } 0}$ that one might see "a bunch of guys unloading a truck full of machine guns ... into some dope house, ${ }^{\prime 1}$ NA developed a musical and performance style most often described in language evoking "brutality." 42 Their "primitive approach" was deliberately "harsh" in pursuit of a "an extreme sound devoid of frills that alternated between violent and mean," ${ }^{43}$ through songs that were extremely short (often

\footnotetext{
${ }^{35}$ George Steinmetz, "Harrowed Landscapes: White Ruingazers in Namibia and Detroit and the Cultivation of Memory," Visual Studies 23, no. 3 (2008), 211, https://doi.org/10.1080/14725860802489890.

${ }^{36}$ Jamie Ludwig, “'There's No Shortage of Blood and Crazy Motherfuckers': An Interview with John Brannon of Negative Approach," Vice (blog), December 9, 2013.

${ }^{37}$ Griffin, “Tied Down-Negative Approach.”

${ }^{38}$ Consider NA roadie and Heretic vocalist Tim King's comment that "When anybody actually does look at Detroit hardcore, they automatically go to Negative Approach." Quoted in Rettman, Why Be Something, 156.

${ }^{39}$ Callwood, "Three Chords."

${ }^{40}$ Brian Hyland, quoted in Rettman, Why Be Something, 85.

${ }^{41}$ Jon Katz, quoted in Rettman, Why Be Something, 86.

42 "Negative Approach.” Interview with John Brannon. Punk News for Punx!, MPRV News. August 14, 2018, https://www.youtube.com/watch?v=QMOpaUkU818.

${ }^{43}$ Callwood, "Three Chords"; Kantor, "Artist Biography."
} 
thirty seconds or less) even for a hardcore genre that deliberately renounced the conventions of both standard and progressive rock. The band's intensity was largely achieved through Brannon's "lungshredding howl," a "harsh weapon of primal power" that sacrificed "any subtlety or even annunciation" 44 in pursuit of an "intense aura" intended to "fuck shit up" 45 by "[whipping] people into a frenzy." ${ }^{46}$ And in performance, Brannon "became a man possessed" ${ }^{" 7}$ as he doubled down on that intensity: "his face [turned] red and his eyes [bulged] out as if the inner rage [would] surely send blood streaming through the sockets at any moment," 48 as he would "stomp side to side like some street-thug, staring down anyone stupid enough to catch his wide, wild eyes ... like he wanted to mercilessly pummel everybody in the room." ${ }^{49}$ Over the decades, Brannon himself has validated such assessments, frequently using language like "fucked up,"50 "violated," and "brutal" 52 to describe his band's sound and his affective performance intentions. I quote liberally here not to avoid my own assessment but instead to establish the consensus of NA and Brannon as purveyors of a singularly aggressive aesthetic, one that we might consider as a correlate to ruin iconography: geographic "abandonment and decay" transformed into a vicious sound bespeaking "the dark side of modernity" ${ }^{\prime 3}$ on which Detroit is often believed to sit.

That correlation is initially complicated by Brannon's overt lack of political pretension. Speaking as primary songwriter-though he shares many co-writing credits with drummer Chris "Opie" Moore, guitarist Rob McCollough, and bassist Pete Zelewski, he is the only writer listed on every track, and always served as the band's spokesman-he described the songs in 2018 as "universal anthems" about teenage "hassles," h4 hardly political articulations of that "dark side of modernity." Yet what I mean to situate here is less intention or conscious awareness than affect; backed by his band's ferocity, Brannon's expressions operate more as timbral assaults than they do complaints or cries for help.

One might even be forgiven for calling the music nihilistic. Consider "Nothing," the only song the band recorded for both its self-titled EP and their LP Tied Down (the entirety of their primary output). The song's intense pessimism is best captured in its final stanza:

I'm always told things I don't want to hear

My destiny's become quite clear

Life's never fucking given nothing to me

It's just stood by and watched me bleed ${ }^{55}$

"Hassles" feels, at best, an understatement. Even more vicious than the lyrical sentiment is the outro that follows these lyrics: Brannon repeats the title via a "glass gargling" guttural vocal style ${ }^{56}$ while the music veers violently into an accelerando until its disorienting caesura. The effect is far more musical than it is

\footnotetext{
${ }^{44}$ Mike Gitter, "Negative Approach 2013: A Chat with Singer John Brannon,” Noisecreep, March 12, 2013.

${ }^{45}$ John Brannon, quoted in Zabe Holloway, dir., "Detroit Punks Episode 1: John Brannon,"

https://www.youtube.com/watch?v=jFaXYsdEsGs.

${ }^{46}$ Ludwig, “There's No Shortage."

${ }^{47}$ Callwood, "Three Chords."

${ }^{48}$ Tesco Vee, quoted in Rettman, Why Be Something, 88.

${ }^{49}$ Callwood, "Three Chords."

${ }^{50}$ Brannon, quoted in Rettman, Why Be Something, 148.

${ }^{51}$ Brannon, quoted in Holloway, "Detroit Punks."

52 Punk News for Punx!, "Negative Approach."

${ }^{53}$ Apel, Beautiful Terrible Ruins, 3, 5.

${ }^{54}$ Punk News for Punx!, "Negative Approach."

${ }_{55}$ Negative Approach, "Nothing," recorded 1982, track 5 on Negative Approach, Touch and Go Records, 1982; also recorded 1983, track 5 on Tied Down, Touch and Go Records, 1983.

${ }^{56}$ Gitter, "Negative Approach 2013."
} 
literary-in large part because, quite frankly, you usually cannot understand what Brannon is saying anyway - an expression delivered through the destructive intensities of band interplay far removed from any singer-songwriter tradition.

Audio Link: http://dx.doi.org/10.3998/mp.2340; https://youtu.be/iOTPK2Sdz.ps.

Example 1: Negative Approach, "Nothing," recorded 1982, track 5 on Negative Approach, Touch and Go Records, 1982, re-recorded, 1983, track 5 on Tied Down, Touch and Go Records, 1983.

In this song, the primal expression of "nothingness" begs to be heard in its historical and geographic context, not simply as a reference to "universal" themes like "hassles" but also as a correlate to its ruined surroundings. What I highlight here (and throughout my argument) is less the song than the performance, by which I mean the immediacy—whether imagined now or experienced then-of the fury expressed or experienced by the young men in those environs. The performance of a song like "Nothing" in Cass Corridor-or even on the releases, recorded and disseminated by the scene that centered there, and with minimal if any overdubbing - should be understood in relation to the audiences for whom it was written, as well as the surroundings in which they heard it played. Thus might we correlate the nihilistic brutality of the performance to the troubling context in which it was performed.

Put another way, I consider Brannon's performative fury here within the old rock 'n' roll standby tradition of "imagined authenticity," wherein "uncompromising, soul-baring artists" are believed to perform their personal truth. ${ }^{57}$ Much of Brannon's mystique is indeed constructed on a pretense of authentic honesty. His peers describe him as a "madman" whose intensity is "very raw, very real, very essential," ${ }^{8}$ suggesting that the fury was unmediated by craft or control. He similarly suggests the songs came in an intuitive flurry, claiming he wrote the first EP tracks "in two weeks on a $\$ 50$ guitar" without knowing what he was doing. ${ }^{59}$ We can certainly question the accuracy of this DIY punk-rock claim (especially given that he shares cowriting credits on half of those songs), but it clearly evinces a desire to communicate a sense of honesty, immediacy, and authenticity.

But does that authenticity (whether real or imagined) necessarily mean we can correlate the expression of NA specifically with their Detroit surroundings? Especially given that much of U.S. American hardcore at the time prided itself on being "refreshingly honest," ${ }^{60}$ perhaps NA's authenticity would better be contextualized generically rather than geographically. However, one way in which we might "hear" Detroit in NA's music is by identifying their particular intervention into that larger national early 1980s hardcore scene. There are undoubtedly both aesthetic and sociopolitical connections between the Detroit and more canonized coastal scenes. ${ }^{61}$ In terms of the aesthetic, most hardcore punk trafficked in the same intense speed as did NA songs; hardcore was music "boiled ... down to its essence, then revved up [to the tempo] of a pencil impatiently tapping on a school desk." ${ }^{2}$ The genre's best-known vocalists—consider Henry Rollins

\footnotetext{
${ }^{57}$ Elizabeth L. Wollman, The Theater Will Rock: A History of the Rock Musical: From Hair to Hedwig (Ann Arbor: University of Michigan Press, 2006), 8, https://doi.org/10.3998/mpub.119496.

${ }^{58}$ Holloway, "Detroit Punks.”

${ }^{59}$ Brannon, quoted in Rettman, Why Be Something, 53.

${ }^{60}$ Callwood, "Three Chords."

${ }^{61}$ I hardly mean to suggest that the only hardcore music being produced in the 1980s was centered in Detroit or on the coasts. Indeed, exciting music was being produced in locations as diverse as Ohio, Nebraska, Pittsburgh, and even Canada. However, I focus on the contrast (between Detroit and the coastal scenes) both because this reflects the general canonical conversation (in which Detroit is sometimes mentioned, albeit as an outlier), and because, even at the time, musicians playing in these smaller scenes drew inspiration from the more well-known coastal bands.

${ }^{62}$ Azerrad, Our Band, 13-4.
} 
of Black Flag or Ian MacKaye of Minor Threat—-tended towards guttural growls that to some ears might seem indistinguishable from Brannon's or even from that of the more generalized punk rock movement of the late 1970s. Further, its "undiluted, unglamorous, and uncompromising" songcraft kept the focus less on lyrical meaning than on expressions of "teenage male angst and frustrated energy," 63 all versions of authenticity.

Sociopolitically, much hardcore was more explicitly political than was NA, but regardless of the musicians' intentions, bands usually positioned themselves as reaction to the "shallow, complacent" conformity of "the greedy, materialistic Reagan era." ${ }^{64}$ They did not always sing about politics, but they saw themselves as causally related to a political landscape. Like the kids in NA, hardcore musicians typically came from the suburbs, resisting not necessarily the system itself so much as the people in it, the jocks and yuppies whom they were happy to alienate through "nasty, brutish distortion." ${ }^{65}$ And even for musicians that did not necessarily hail from the suburbs, ${ }^{66}$ the temptation to construct their scenes in urban environments reflected more than just the city's geographic centrality; the city, as a political landscape that highlighted the social inequities of the Reagan era, offered a metaphoric expression of what Penelope Spheeris termed "the decline of Western civilization" in her landmark documentary of the early 1980s L.A. hardcore scene. ${ }^{67}$

All of this generic context certainly applies to NA to various degrees, and yet I contend that their situating in Detroit singularly frames the music, imbuing it with the power to evoke a distinct, and ultimately more pessimistic, vision of the U.S. at the time. While other seminal coastal hardcore bands came from the coasts-Black Flag and the Circle Jerks from Los Angeles County, Minor Threat and Bad Brains from Washington, DC-and were attempting to uncover some hidden layer of ugliness beneath the sheen of Reagan's America, NA was a Midwestern band whose "nasty, brutish distortion" was not ironic counterpoint to any sheen but instead a reinforcement of self-evident ruin. There was nobody to shock in Cass Corridor, so NA and their peers were not mocking or indicating or expressing a political dissatisfaction, but instead creating within the material ruins of that political dissatisfaction. Detroit audiences did not need a lesson on the dark undercurrents of "American exceptionalism"; it had already been abandoned as a failure of such. Put another way, while the Los Angeles bands of The Decline of Western Civilization reference their city's urban blight, often with explicitly political songs, it is telling that they were not playing their shows in Watts, the L.A. neighborhood devastated by riots in 1965 as Detroit later was in 1967. Unlike the Detroit-centered musicians, they had other options, and thus interacted neither materially nor symbolically with the aftermath of their city's "ruins." ${ }^{\prime 8}$ So, again referencing the epigraph, while Ian MacKaye was shocked to see the music and slam-dancing beget a riot amid the rubble, Brannon took it for granted.

\footnotetext{
${ }^{63}$ Ibid., 130.

${ }^{64}$ Ibid., 8, 74 .

${ }^{65}$ Ibid., 16.

${ }^{66}$ Consider seminal hardcore figures like Alice Bag or Darby Crash (Germs) in Los Angeles, or Harley Flanagan (Cro-Mags) in New York City, all of whom were lifelong city dwellers.

${ }^{67}$ The Decline of Western Civilization, directed by Penelope Spheeris (Atlantic Television, 1981). Spheeris's film, which has been recognized as significant by the U.S. Library of Congress, offers many great examples of how the L.A. scene contrasts with the Midwest scene.

${ }^{68}$ I do not mean to suggest any easy equivalence between the Watts and Detroit riots, nor between their lingering effects on the disparate locations. In musical terms, consider that the former hosted its famed "Wattstax" concert shortly after the riots, which had no equivalent in downtown Detroit. I use the comparison only to illustrate how Los Angeles did not carry the same symbolic weight or suffer a similar material degradation as did Detroit, meaning whatever corollary music in the former scene has with the "ruin" would better be considered as mostly metaphoric or political, whereas music in the Detroit scene correlated to both a metaphoric and material reality.
} 
The general critical appraisal of NA as exceptionally brutal can thus be understood to reference not merely the band's aesthetic intervention, but also its sociopolitical one. If indeed we read the music as political-as I certainly do - then NA is not mocking the complacency and conformity of middle-class life, but instead is eschewing middle-class life for the depravity of its urban double, positioning their distortion in the midst of a degraded neighborhood in the middle of the nation's murder capital in the early days of a crack epidemic. ${ }^{69}$ So situated, the music has a sociopolitical affect despite the lyrical avoidance of political utterance, an affect whose correlation with its Detroit setting offers comment on a culture's ability and willingness to so brazenly betray itself with little regard for those left behind, a betrayal that we might again be justified in calling nihilistic.

More specifically, the correlation (between the music and its social situating) can be identified not merely as abstracted intensity or brutality, but also as one directly evoking the concept of ruins. I hear this in the music in two ways. The first concerns its relation to Detroit's musical legacy. The promise of pre-riot Detroit was not only economic and social, but also musical. As Brannon puts it, "everything that was to become music later on, I think, started in Detroit, in one form or another." ${ }^{\text {"70 }}$ The city had boasted a vibrant blues and jazz scene as early as the 1920s, but its peak came with Motown Records in the 1960s. An almost exclusively Black American company, Motown was founded and managed by Berry Gordy, who has often told the story of how, when working at the Lincoln-Mercury plant, he developed both his company ethos and his musical aesthetic alongside the industrial rhythm of the factory's assembly line, a conflation that only underscores this metaphoric synergy linking money, race, music, and promise in Detroit. ${ }^{71}$ As a "meritocracy" enabled by the city's economic stability, Motown music was hyper-controlled (both in terms of process and content), and its success has long been understood as parallel to its city's potential during the pre-riot decade. $^{72}$

The city's musical legacy did not end with the riot, though. For certain underground rock fans, Detroit's diminished condition in the 1970s (the first post-riot decade) facilitated raucous music as equally iconoclastic as Motown was culture-defining. Bands like Alice Cooper, the Stooges (with its charismatic, Puckish frontman Iggy Pop), and the MC5 developed a mode of "proto-punk" that "stood out from the rest of the hippie counterculture of the time by blasting an ass-kicking din that displayed all the anger and turmoil that surrounded their city." ${ }^{\text {"3 }}$ They were seen not only as bands from Detroit, but also of Detroit. Yet this music was hardly as "underground" as were NA or other hardcore groups of the 1980s. Though far less refined than the music of Motown, this proto-punk style was nevertheless part of a national conversation; bands courted and were signed to major labels, and they toured nationally, sometimes to great success. The music of these "proto-punk" bands engages easily-identified blues and rock idioms that date back to the 1950s, so while their attitudes and raucous playing inspired the punk rock movement, there was little in their approach that could be termed structurally destructive, unlike the more vicious rhythms of hardcore. Like the music of Motown, this 1970s music reflected its city both through noted correlations to the city's perceived condition at the time, and as its de facto ambassadors to the mainstream. ${ }^{74}$

\footnotetext{
${ }^{69}$ Jay and Conklin, A People’s History, 210; Mock, “'This ain't no love-in,”, 206.

${ }^{70}$ Punk News for Punx!, "Negative Approach."

${ }^{71}$ Maraniss, Once in a Great City, 50.

${ }^{72}$ Maraniss, Once in a Great City, 49-50, 47, 232, 62.

${ }^{73}$ Rettman, Why Be Something, 1.

${ }^{74}$ I should note that I speak in generality here; as an example, one could easily identify the destructive tendencies in the Stooges' Fun House. However, I justify the generalization owing to the renown that these three bands enjoyed and continue to enjoy in the larger rock (not merely punk rock) canon.
} 
Brannon cites those three bands as important inspirations,${ }^{75}$ and yet the music of NA makes no similar overture to the mainstream. In fact, its relation to traditional rock idiom is a destructive, not affirming, one. With their abrasive edges and jagged, strident timbres, NA songs could even be read as "disordered, unregulated spaces of ruins," 76 ruins not of the material city but of that faded promise we might similarly correlate with the hyper-controlled, smooth sounds and inventive compositions of Motown. There are inventive riffs, timings, and musical figures throughout the NA oeuvre, ${ }^{77}$ but the frenetic arrangements and intense speeds typically prioritize the assault over the construction. Contextualized temporally, then, we might hear in NA a response to a legacy of rock that has degraded to its jagged essentials. As music scholars sometimes connect the heights of some common practice compositions to the sublime appeal of classical ruins, ${ }^{78}$ so might we also see NA's compositions as reflections of the more modern, "industrial ruins ... structurally dangerous architectural hulks subject to the depredations of strippers, urban explorers, animals, weather, and other forces." ${ }^{\prime 9}$ Brannon notes that he wrote the songs from the band's first EP as modifications of "Jumping Jack Flash," the only song he knew, ${ }^{80}$ which makes of his decidedly non-blues based songs ruins of one of rock's most canonized, mainstream acts. That this music was made in Detroit for its audiences should not be simply relegated to incidental circumstance; instead, that context positions the music as rubbled response to what had once been recognized as a height of musical promise.

As a concrete example of what I mean by an "industrial ruin" in musical terms, let us consider "Pressure," one of NA's notoriously short songs. While their songs overall average about thirty seconds in length, "Pressure" is particularly fragmented at just over nine seconds long. "Pressure" is provocatively jagged not only in its timbre but also in its sudden, culminating caesura, which leaves the listener with a dizzying inertia, especially if they happen to be slamming along to it. ${ }^{81}$ This fragmentary quality was not simply some accident of limited talent, but was in fact a consciously engaged mode. In fact, the brevity of NA songs in general was meant to be provocation: as Brannon says, "dudes from the more established rock bands in the area were offended we had the nerve to go on stage and do that." ${ }^{" 2}$ Furthermore, while hardcore music typically included short songs, NA songs are far shorter than those of many of their contemporaries, which underlines how deliberately employed that mode was for them. ${ }^{83}$

Audio Link: http://dx.doi.org/10.3998/mp.2340; https://youtu.be/dfvDHgejJmQ.

Example 2: Negative Approach, "Pressure," recorded 1982, track 3 on Negative Approach, Touch and Go Records, 1982.

\footnotetext{
75 Punk News for Punx!, "Negative Approach.”

${ }^{76}$ Ibid., 69.

${ }^{77}$ See my discussions of "Nothing," "Pressure," "Ready to Fight," and "Why Be Something that You're Not," below.

${ }^{78}$ See, for instance, Tekla Babyak's "The Rubble of the Other," in Historians Without Borders, ed. Lawrence Abrams and Kaleb Knoblauch (London: Routledge, 2019), or Richard Kramer's “The Hedgehog: Of Fragments Finished and

Unfinished," 19th-Century Music 21, no. 2 (1997), https://doi.org/10.1525/ncm.1997.21.2.02a00020.

${ }^{79}$ Apel, Beautiful Terrible Ruins, 13.

${ }^{80}$ Rettman, Why Be Something, 53.

${ }^{81}$ Negative Approach, "Pressure," recorded 1982, track 3 on Negative Approach, Touch and Go Records, 1982.

${ }^{82}$ Brannon, quoted in Rettman, Why Be Something, 79.

${ }^{83}$ As evidence, consider the average lengths of songs from NA's self-titled EP and their Tied Down LP against those other bands in the Touch and Go stable from the time or songs from Black Flag's or Minor Threat's early releases. Negative Approach s/t EP: average $53 \mathrm{sec}$.; Black Flag's Damaged: average 2 min., 20 sec.; Minor Threat s/t EP: average 1 min., 16 sec.; Necros LP Conquest for Death: average $1 \mathrm{~min}$., $40 \mathrm{sec}$. On the first Touch and Go compilation, Process of Elimination, the average song length is $1 \mathrm{~min} ., 17 \mathrm{sec}$; the NA contribution, "Lost Cause," at 36 seconds, is one of three under a minute long. One could see a possible exception in NA's LP Tied Down (song length average: 1 min., 41 sec.), but a suitable contrast for that would be Minor Threat's first LP Out of Step (song length average: 2 min., 24 sec.), suggesting that the hardcore bands saw the LP form as opportunity to stretch a bit.
} 
In the case of "Pressure," earlier versions of the song support such a reading. ${ }^{84}$ The earliest recordings reveal both that its brevity was always part of its construction - this is one of the songs Brannon claims he wrote alone on his cheap guitar-and that the beginning and ending sections initially used a slower tempo than did the faster middle section. At this slower velocity, the performance and arrangement signpost the song's ending by emphasizing the heterogeneity of the distinct sections; a dynamic construction, it is short but feels complete. The canonical arrangement, as released on the Negative Approach EP and which survived in live performances from the early 1980s until at least November 2019, employs the same abrasive, breakneck tempo throughout, a tempo that obscures the construction in favor of a jagged, fragmentary affect. The sections bleed into one another, obscuring its construction in favor of its bite.

Audio Link: http://dx.doi.org/10.3998/mp.2340; https://youtu.be/PQW0cFHgmZ8.

Example 3: Negative Approach, first known recording of "Pressure," as released on Nothing Will Stand in Our Way. Taang! Records. 2011.

I suggest we might hear that fragmentary quality as a correlate to the setting in which it was created. Ruin studies have long connected the concept of the artistic "fragment" to the material ruin: Andreas Huyssen notes that the architectural ruin in the imaginary "privileges fragment and aphorism" over the premise of the whole $;^{85}$ Richard Kramer suggests that a musical fragment functions as a "ruin ... evocative of something lost and irretrievable." ${ }^{86}$ Applying this concept to the ruins of Cass Corridor makes that area's rubble doubly profound, since it both signifies the disappearance of the now-lost whole and threatens danger as materially jagged concrete or crumbling cement. Brannon's songcraft in "Pressure" similarly straddles this binary, operating as a metaphoric fragment of his city's musical legacy and as a befuddlingly, affectively incomplete piece of work.

I do not mean to suggest Brannon or his fellows were theorizing the ruin through their music, but neither do I want to dismiss its inherent correlation to the ruins in which it was created to be performed. As scholars have connected common practice compositions to classical ruins regardless of composer's intention, so do I suggest that the rubbled landscape of Cass Corridor is reflected within the aesthetic mode of NA's music, thus allowing it to speak "of something lost and irretrievable," 87 a political, economic, and social possibility that has been subsumed by ruins bespeaking that possibility's failure. The aesthetic intensity and "brutality" of NA, then, can be heard not simply as sped up resistance to the everyday concerns detailed in the lyrics, but rather as a musical expression born of its time and place, both of which spoke of and continue to signify a political history of betrayal, neglect, and pessimistic determinism that can easily justify a "negative approach.”

\section{The Constellation of Cass Corridor}

They're always talking shit. I don't know, man. That's where I live, that's where my mom lives, that's where I grew up. I love Detroit. They always try to make it out to be an apocalyptic wasteland where 70 thousand rabid dogs are running down the street. I mean . . there are places

\footnotetext{
${ }^{84}$ Negative Approach, Nothing Will Stand in Our Way, Taang! Records, 2011. This compilation contains many early versions of NA songs.

${ }^{85}$ Huyssen, "Nostalgia for Ruins," 11.

${ }^{86}$ Richard Kramer, "The Hedgehog," 144.

${ }^{87}$ Kramer, "The Hedgehog," 144.
} 
that are bad, there are places that are good, but you should try to stay out of trouble and you should probably carry a weapon. ${ }^{88}$-John Brannon, 2013

Critics might feel justified in their assertion that NA's sound is one "that could have only come from Detroit." ${ }^{89}$ As a ruin of U.S. political efficacy cauterized in the early 1980s into rubbled landscape like that of Cass Corridor, Detroit's metaphoric appeal is one that bleeds not just into discourse but into our reading of performance born especially from bands like Negative Approach, whose synergy with the city is so materially apparent. However, NA's story is not quite so simple. Indeed, further analysis of the band's relationship to the community, as well as of the more complex ambivalences in its music, offer us equally a way to problematize the cultural tendency for ruin fetishization. No matter how well it holds, symbolic articulation is not always available or efficacious for those who live and work in what those outside might term a "ruin" landscape. Below, I will position Brannon and NA's connection to Detroit as one that does not merely reflect a political/social reality, but in fact embraces that reality, admitting its decay without relegating it to the status of codified endpoint. NA's music and story, I will argue, straddle a liminal ambivalence within the constellation of Cass Corridor, one bespeaking both vicious negativity and vivacious creativity, thereby characterizing decay not merely as reference to the past but also as call towards the future. While their work embraces the rubble, it also refuses to let Detroit become simply a ruin.

The work of anthropologist Gastón R. Gordillo is useful here in understanding the problematic limitation imposed by positioning any landscape in terms of an "imaginary of ruins." While that concept designates ruins as symbolic, "aestheticized" confrontations with a settled past, ${ }^{90}$ Gordillo's study of Argentine ranchers and farmers presents a more nuanced reading of ruins and rubble as "constellations defined by their afterlife." "G1 Gordillo reclaims the value of "mere rubble" — worthless debris" that do not necessarily indicate any romanticized depth or meaning the way that "ruins" might ${ }^{93}$ - as not aestheticized but rather as a profound "multiplicity" that neither dismisses the presence of the past nor fixates upon it at the cost of positive, creative action. ${ }^{94}$ Rubble in this case constitutes "unfinished products, processes in the making," 95 processes which those who live and create among them cannot fix as codified symbol but must instead confront as living reality. Put simply, Gordillo positions rubble as an essentially liminal phenomenon, "textured, affectively charged matter" that points to the future ironically by signifying a fixed past. ${ }^{96}$ It is an irony easily applied to Detroit. Jerry Herron's work, for instance, speaks of Detroit as having a "death-in-life existence ... at the border of city and not-city," as a place "emptied out" but "hardly over,"

Indeed, Brannon's positionality within Cass Corridor in the early 1980s was itself an ambivalent one. On one hand, he has long framed himself and his band as symbiotic with Detroit: in 2018, he described NA's early music as response to "the craziness of the city"; he cites "local bands" like the MC5, the Stooges,

\footnotetext{
${ }^{88}$ Quoted in Ludwig, “'There's No Shortage.”

${ }^{89}$ Kantor, “Total Recall."

${ }^{90}$ Huyssen, "Nostalgia for Ruins," 8.

${ }^{91}$ Gordillo, Rubble, 5.

92 Steinmetz, "Harrowed Landscapes," 216.

${ }^{93}$ Gordillo, Rubble, 5.

${ }^{94}$ Ibid., 2.

${ }^{95}$ Ibid., 151.

${ }^{96}$ Ibid., 5.

${ }^{97}$ Jerry Herron, “Borderland/Borderama/Detroit,” Places Journal (July 2010), https://doi.org/10.22269/100706.
} 
and Alice Cooper, as his primary inspirations, ${ }^{98}$ in the early 1980s, part of his reputation in the scene was built on being one of the few musicians who actually lived in Cass Corridor; and outside of a few years in Ann Arbor, he has spent his entire adult life there.

Yet technically, Brannon might be of Detroit but is not actually from Detroit; he was mostly raised in Grosse Pointe Woods, one of the metropolitan area's wealthiest suburbs. In fact, several of the band's original members came from the suburbs, as did much of the talent and audience of the Detroit hardcore scene overall. ${ }^{99}$ To whatever degree Brannon developed a symbiotic relationship with Cass Corridor, he did so from a place of geographic privilege. Today, a twenty-minute drive will bridge the distance between the manicured neighborhood streets of Grosse Pointe Woods and the destitute, abandoned urban areas that fascinate journalists and ruingazers alike. The exclusive community of Grosse Pointe offers a particularly resonant expression of the urban/suburban divide; it was both hometown to Henry Ford II and the site of a 1960 national redlining scandal. ${ }^{100}$

Like many other suburban punks, Brannon unsubtly detested his community's conformity, and traces the root of his anger to the class divide that marginalized his lower middle class family from Grosse Pointe's ultra-privileged wealthy. ${ }^{101}$ That anger quickly found its expression in music; he formed his first bands with Pete Zelewski, a fellow jaded, punk-loving outcast. ${ }^{102}$ In 1982, Brannon identified his songwriting inspiration as "People I hate"; ${ }^{103}$ in 2013 , he was still repeating that sentiment. ${ }^{104}$ His relationship to the art he made and the city where he made it can be understood, then, as much by what he was repudiating as by what he was embracing.

Suburban disaffection is central to the story of much American hardcore (and, indeed, much underground art), but while bands from New York City or Orange County were "embarrassed by coming from" the suburbs, the members of the Detroit hardcore scene "considered it a badge of honour," since they were deliberately choosing to make their art—and for some like Brannon, their homes_- "in a particularly bad-ass city." ${ }^{105}$ NA's synergy within the constellation of Detroit is not just figurative but geographic, the ruin of Cass Corridor indicative of both the city's struggles and the bourgeois complicity in perpetuating them. Engaging this geographic constellation, NA and their peers highlighted through their agency the creative, future-facing potential of the rubble; they were well aware of their life options, but saw freedom by eschewing their privilege in order to create in an area presumed dead and gone.

One could read Brannon's suburban upbringing less generously, his "blue-collar, I-live-in-Detroitso-fuck-you" 106 anger as a put-on: that a young man in his early twenties chooses to live in squalor does not necessarily constitute productive rebellion. However, to whatever degree such dismissal applies to Brannon as a man, it further, productively, complicates him as an artist, particularly since it problematizes the very idea of him and his rage as "authentic" in the first place. Presuming his anger reflects Detroit as itself as a rage-filled city relies on the idea of Brannon the performer as authentically experiencing or embodying his rage, rather than performing it. Much of the band's reputation, as previously detailed, is built precisely on

\footnotetext{
${ }^{98}$ Punk News for Punx!, "Negative Approach."

${ }^{99}$ Rettman, Why Be Something, 75, Mock, “'This ain’t no love-in,” 204.

${ }^{100}$ Sugrue, Origins, 203, 193.

${ }^{101}$ Callwood, "Three Chords."

${ }^{102}$ Pete Zelewski, quoted in Rettman, Why Be Something, 52.

103 "Why Be Something You're Not.” Cable Access Show. Detroit, MI. 1982, https://www.youtube.com/watch?v=ms4lupbshtc.

${ }^{104}$ Jacob Katel, "Negative Approach: You Can’t Kill Hardcore," Miami New Times, October 21, 2013.

${ }^{105}$ Mock, “"This ain't no love-in," 204.

${ }^{106}$ Callwood, "Three Chords."
} 
such presumptions, of Brannon as a "madman" and so on. I want now to challenge such a simple framing, not to diminish the affect of NA's music but instead to suggest how it, as constructed art, provides a lens through which to challenge our concept of Detroit as a disintegrated landscape.

Most pointedly, I believe Brannon's presentational style should best be understood as performative. That concept (performativity) was first developed in terms of language by philosopher J. L. Austin in 1962, but has since been applied to a variety of contexts; in the sphere of performance studies, it applies to performance that does not merely describe or identify a phenomenon, but instead produces, enables, or reinforces a new phenomenon, creating a social reality rather than imitating one. ${ }^{107}$ Much rock performance that hinges on the concept of "authenticity" can be understood as mimetic, as imitation of the subject's (usually the singer's) inner emotional state; a performative rock presentation, on the other hand, would be judged in terms of what it manifested, how it affected the world. I find the concept fruitful in the case of Brannon for three reasons: first, it allows us to avoid the slippery criteria of "authenticity," which as previously discussed has particular resonance if we connect the band to its city; second, the performative almost necessarily implies a symbiosis with the audience on or for whom it acts, and as I will discuss, audience relationship is a central part of NA's story; and lastly, the performative implies a discursive quality that will help elucidate how this music correlates with its temporal and geographic setting. What I mean to identify in my analysis of the care, craft, and control implicit in NA's seemingly nihilist style is an inherent contradiction that can be read as both cathartic celebration and destructive assault, as an ambivalent "negative approach" that references a rubbled past while pointing towards the virtue of constructive communitybuilding.

Performative affect almost necessarily requires some degree of forethought, design, and control, which I believe one can identify in both NA music and Brannon's performance style. While hardcore is sometimes maligned as a primitive form employed by inexperienced or untalented musicians - the implication being that they would play "better" if they could-Brannon, like many of his peers in the scene, definitely understood the mode as crafted aesthetic. He was not relegated to hardcore: he chose it. His earliest musical output was with a "glam punk" band called Static, which was more New York Dolls than Black Flag, owing to its kitschy, flamboyant theatricality: on stage, Brannon would cover himself with toothpaste. ${ }^{108}$ Not until Brannon saw the Ohio band Necros open for Black Flag did he decide to end Static and form NA; the choice was made consciously, inspired both by the musical mode of hardcore and by the community that formed around it: it was "a whole different world that [he] wanted to be a part of." ${ }^{109}$ His later bands, which situate his ferocious vocal style into very different contexts, illustrate his facility for distinct musical modes: the Laughing Hyenas (1985-95) traffic in raunchy-blues, while Easy Action (2001-present) engages the style of early 1960s garage rock. ${ }^{110}$ Even in NA, Brannon had ambition to build from the stylistic innovations of artists like Oi! and David Bowie. ${ }^{111}$ The unfiltered aggression of NA hardcore, then, should be understood not simply as unadulterated, spontaneous, "authentic" expression, but also as a consciously chosen sonic site in which to devise a style.

Similarly, the song constructions often belie any pretense of spontaneity. Brannon's earlier cited claim—that he wrote the first EP songs quickly—suggests a lack of mediated process, but that claim is

${ }^{107}$ Jillian R. Cavanaugh, "Performativity," Oxford Bibliographies Online, last modified March 10, 2015, https://doi.org/10.1093/obo/9780199766567-0114.

${ }^{108}$ Rettman, Why Be Something, 52.

${ }^{109}$ Brannon, quoted in ibid.

${ }^{110}$ Gitter, "Negative Approach 2013."

111 Punk News for Punx!, "Negative Approach." 
problematized both by the organization of the songs and by the fact that half the songs on that first EP were co-written with other band members. I mention this not to doubt Brannon's integrity, but to suggest that his performative rage can also be understood as a consciously-engaged affect he (and sometimes his cowriters) achieved through certain songwriting modes. They were considering not merely their own internal emotional states but also the audience for whom the music was supposed to function.

Consider again the song "Nothing," earlier discussed in reference to its nihilistic intensity. While the song supports that analysis, it also employs a relatively structured pop form:

\begin{tabular}{|c|c|}
\hline $0: 00-0: 05^{112}$ & Atmospheric guitar feedback (a rarity among NA songs) \\
\hline 0:06-0:15 & $\begin{array}{l}\text { Accumulative build over continued feedback: bass groove } \\
\text { followed by irregular drumming }\end{array}$ \\
\hline $0: 15-0: 25$ & $\begin{array}{l}\text { Two repetitions of the } 6 \text {-chord verse pattern over an } \\
\text { established } 4 / 4 \text { beat }\end{array}$ \\
\hline $0: 25-0: 36$ & Vocal over verse (repeated 6-chord pattern) \\
\hline $0: 37-0: 45$ & $\begin{array}{l}\text { Vocal over chorus built on a } 3 \text {-chord pattern, ending } \\
\text { in a passing chord that transitions back to verse }\end{array}$ \\
\hline $0: 46-1: 16$ & Repeat of verse and chorus \\
\hline $1: 16-1: 28$ & $\begin{array}{l}\text { Guitar out; feedback over bass functions as instrumental } \\
\text { solo }\end{array}$ \\
\hline $1: 29-1: 36$ & Verse 1 repeats, no chorus \\
\hline $1: 37-1: 50$ & Outro: "Nothing!" is howled repeatedly over verse chords \\
\hline $1: 50$ & Immediate caesura \\
\hline
\end{tabular}

Audio Link: http://dx.doi.org/10.3998/mp.2340; https://youtu.be/iOTPK2Sdz.ps.

Though it employs a relatively conventional pop/rock verse/chorus form, there are a few stylistic adjustments worth noting. First, its lack of a final chorus puts a special emphasis on the outro as the culminating expression. Second, the intensification of that outro, both in the "glass gargling" vocalization and the accelerando, marks that section as autonomous, a quasi-example of what Brad Osborn calls "terminally climactic form." ${ }^{" 113}$ Finally, the immediate transition from that culminating intensity into an affecting silence (both on record and in live performance) engages a contradiction between sonic assault and sudden absence. We can understand these modifications in several ways: in relation to the lyrics, as a stylistic reflection of an existence where meaning breaks down into chaos and then nothing at all, an existence where intensified opposites end in sudden absence; as musical concepts independent of semiotic meaning, a quick but dynamic ride for the audience; or as a structure that provides Brannon space to exercise and demonstrate the singularity of his particular vocal virtuosity. In any of these understandings, the song structure is crucial to unpacking its affect, whether semiotic or phenomenological, for an audience. Nihilism, it seems, can sometimes require an awful lot of deliberation and shape.

That same sense of deliberate control is assessable in the singer's performance style, his eye-bulging red-faced performance affect of "primal power." "Arguably more so than even the songs, NA's reputation

\footnotetext{
112 While the exact timestamps are drawn from the s/t EP performance, the relative structure is consistent both in its recording on the LP and in live performances.

${ }^{113}$ Brad Osborn, "Subverting the Verse-Chorus Paradigm: Terminally Climactic Forms in Recent Rock Music," Music Theory Spectrum 35, no. 1 (2013): 23-47, https://doi.org/10.1525/mts.2013.35.1.23. The example does not quite fit Osborn's conception, most notably because it repeats the verse chords, but I use it to illustrate the perhaps deceptive immediacy of the song's construction.

${ }^{114}$ Gitter, "Negative Approach 2013.”
} 
for intensity is built on the pretense of Brannon's sense of "me against the audience" as he releases his "frustrations [onto] each person." 115 This pretense of uncontrolled threat is essential to the music's aesthetic effect, but it is nevertheless a sense carefully curated: Brannon knows what he is doing. As he puts it, the performance is meant to be "threatening and exciting ... you might not know what's going to happen."116 Further, he frequently discusses the disconnect between his confrontational performance and his jovial reputation among friends and fans, even on the night of a show, positioning his affective rage as authentic but also condensed and concentrated into his stage work for the audience's sake. As he puts it, "you're not gonna feel that way every day or every minute," 117 and so you might go to a hardcore punk show to process those feelings through a concentrated reflection of them.

Indeed, understanding NA in the early 1980s involves understanding the audience for whom they created and played. In now detailing the context of this audience, I want to highlight how this curated, concentrated musical style worked in synchronicity with its community, and further how those concurrences provide a productively complicated understanding of Cass Corridor. By encouraging a sense of solidarity precisely around their pessimistic, negative emotional affect, in encouraging catharsis through reference to explicit destruction, Brannon and his band created work that performatively contextualized their surroundings in a way that we might find useful even today.

Brannon's intense performative affect-again, "me against the audience"-might have been constructed to some degree, but the persona was meant to be one fundamentally unseparated from his offstage audience. The whole concept of "me against the audience" implies some degree of equal footing, rather than a hierarchy; or, as Brannon put it in 2013: "at that point, there was no separation between the kids and the audience and who's on stage." 118 The identity Brannon performed was one meant to directly engage the young men who came time and again to see his band play.

No doubt much hardcore music was explicitly about building a "scene," generating an audience as much as a style. For instance, The Decline of Western Civilization is largely about the symbiosis between hardcore punk bands and their crowds. However, that does not mean that every hardcore band built their aesthetic approach around this degree of unmediated connection between performer and audience, even in Detroit at that period. As an edifying contrast, we might consider Glenn Danzig of the Misfits, a New Jersey band who played often in Detroit during the early 1980s before achieving a much greater renown. ${ }^{119}$ In her 2014 study of the relationship between the Misfits and Detroit, Roberta Mock cleverly identifies symbiotic connections between Misfits songs-in which Danzig often lyrically embodied zombified or alien creatures, a type of horror-punk - and the "death-in-life" ontology of Detroit. Her argument, that the Misfits' use of "zombie scenarios" played to its early 1980s Detroit audiences as a reflection of their "threshold space of abjection," 120 convincingly suggests how performance metaphor can engage a correlative connection to a temporal or geographic site while offering context for identity-building among the audience within that site.

The contrast with Brannon is edifying here, particularly since NA was largely playing to the same audiences the Misfits did. A performance "scenario" is a mimetic mode, often, as in the case of the Misfits, reliant on recognizable semiotic symbology. Brannon's mode, however, was marked by his directness; there

\footnotetext{
${ }^{115}$ Brannon, quoted in Callwood, "Three Chords."

${ }^{116}$ Ibid.

${ }^{117}$ Brannon, quoted in "For the first time Negative Approach interviewed by the Russian media." Sadwave, September 15, 2014.

${ }^{118}$ Steve Miller, “An Oral History of Detroit Punk Rock,” DaCapo Press (June 2013).

${ }^{119}$ In their reunion shows between 2016 and 2019, the band sold out Madison Square Garden.

${ }^{120}$ Mock, “This ain't no love-in," 202. Mock's positioning of Detroit in terms of "zombie scenario" is hardly her creation; as she acknowledges, the city has regularly hosted zombie-related events over the past few decades.
} 
was less a reshaping of the world into mimetic imitation than there was immediate connection with the kids on the floor, invitation to engage this ambivalent "negative approach" that synthesized both ferocity and fellowship.

It is important, then, to note that this was "an audience of largely teenage boys . . who [were] trying desperately to negotiate their place in the world." 121 Through its performative acknowledgement of the liminality of rubble that populated this "border of city and not-city," 122 NA's music largely functioned not to define any particular "scenario" so much as to resist the ontological certainty of a fixed identity. Their affect encouraged their audience to be "Ready to Fight," as one of their anthems puts it, to declare solidarity not by fixing identity with any certainty, but instead by confidently repudiating what does not belong. These young people were not told in NA songs to know who they were; they were instead asked to proudly declare what they were not. The violence that accompanied the shows-the "punch-ups and flying limbs," 123 the riot at the closing of the Freezer-were part of this idiom of repudiating what does not belong. The aggression was thus ironically a show of solidarity. That is not to say that the violence could not get out of hand, but that usually happened when the Cass Corridor community was attempting to repudiate others who lacked their appreciation for ambivalent solidarity. For instance, the riot referenced in the epigraph was largely directed against a new group of youths who came from the suburbs for the sake of violence itself, "to see who they could beat up," ${ }^{24}$ rather than to enjoy the communal atmosphere engendered through the aggression.

So while Brannon's performance affect certainly engaged a "slippage between 'real' performer, persona and character," 125 to the point of obscuring the line between his personal and performative rage, it was in service of engendering an authentic community; the ambivalence of his ferocious style was one that functioned specifically for young people themselves lost in the ambivalence of their adolescent identities. That the environs of Cass Corridor made such a complicated symbiosis possible helps us to identify it as one not simply of decay but also of potential. The "afterlife" of its rubble facilitated the construction of a community which thrived on its own contradictions.

We can hear ambivalence in the musical constructions as well; consider again the anthem "Ready to Fight," a piece that engages both the positive and negative poles of communal expression. The song has two primary sections, each of which is repeated twice. First comes a basic four-chord structure in standard time, accompanying the verse:

We won't take any shit and we're not about to leave

Just 'cause you don't like who we are and what we want to be

Who are you to say what's wrong and what's right

If it's what it takes, we're ready to fight ${ }^{126}$

These are some of Brannon's most easily-discernible lyrics, almost as if he is explicitly taking pains to be comprehended. Immediately following this section comes a two-chord cacophony over which the drums play a frenetic martial beat as Brannon repeats the title phrase much more aggressively. In the recording, the repeat of these sections employs multiple voices, indicating that the song is intended for crowd interplay, as

\footnotetext{
${ }^{121}$ Ibid., 205.

${ }^{122}$ Herron, "Borderland/Borderama/Detroit."

${ }^{123}$ Mock, “'This ain't no love-in,” 207.

${ }^{124}$ Brannon, quoted in Rettman, Why Be Something, 140.

${ }^{125}$ Mock, “This ain't no love-in,” 202.

${ }^{126}$ Negative Approach, "Ready to Fight," track 6 on Negative Approach, Touch and Go Records, 1982.
} 
indeed the lyrics also suggest: the use of the first-person plural ("we") stands as stark contrast to Brannon's more frequent use of the singular "I" ("Pressure," Nothing," "Can't Tell No One") or second person "you" ("Tied Down," "Why Be Something that You're Not," "Negative Approach"). Notably, the two sectionsthe verse and the two-chord cacophony-are not cohesively linked. The verse section operates at a controlled speed that allows for fist-pumping solidarity, before it ceases entirely. The latter section charges out of that momentary silence, undisciplined and aggressive. That violence can veer between guarded solidarity and unhinged release is the musical, if not lyrical, point. Brannon in fact has discussed this ironic, cathartic potential of his violent intensity, noting that the harsh directness of NA performances is meant to make him "feel better." 127 "A preacher's son"-his first memory of singing was with a church choir-he "[takes] you to church in his own way," pessimistic though it may be. ${ }^{128}$ That his church was willing to court destructive energy may seem paradoxical to some, but as it was designed for young people seeking to find themselves in the rubble of Detroit, its willing embrace of contradiction should hardly be viewed as demerit.

Audio Link: http://dx.doi.org/10.3998/mp.2340; https://youtu.be/b1-KD5Xav-Q.

Example 4: Negative Approach, "Ready to Fight," track 6 on Negative Approach, Touch and Go Records, 1982.

Symbiosis with its audience was central to NA not only in their music but also in the material conditions that facilitated their performances. Its reputation among the "constellation" of Detroit's rubbled Cass Corridor was defined as much by their connection to their scene as it was by the music they made. When Brannon says he and his peers "created a scene out of nothing," he speaks of not only the musicians but also the loyal audiences, ${ }^{129}$ a "true brotherhood amongst friends" who saw "Support Midwest hardcore" as a "call to arms," 130 in the words of one of the band's early roadies. For this community, the rubble of Detroit was not an unfortunate necessity but part of a constellation that facilitated their site for identity construction. Unable to play larger Detroit clubs because of their age, the musicians constructed the Freezer Theater from a decaying abandoned storefront. ${ }^{131}$ And unable to attend shows at bars, the underage audience needed places like the Freezer and largely neglected neighborhoods like Cass Corridor. After the Freezer was demolished, the community constructed the Clubhouse nearby, building their own stage and even a loft where Brannon lived with his girlfriend Larissa Strickland, herself a fixture on the scene through her band L-Seven. ${ }^{132}$ Many of NA's shows at the Clubhouse were actually fundraisers to replace their perpetually stolen equipment; ${ }^{133}$ the band was materially, not just emotionally, reliant on their audience. Most of the scene's releases were produced and packaged by the community's own DIY operation Touch and Go Records, which still exists today. ${ }^{134}$ Many of the bands organized a short-lived local cable-access program called "Why Be Something You're Not," featuring interviews and musical performances, many now thankfully available via YouTube. Filmed in an empty television studio on off-hours, with a spray-painted bedsheet for stagecraft, the operation employed a scrappiness that articulates the positivity of a scene that saw potential in the problematic, fragmentary rubble of their surroundings.

\footnotetext{
${ }^{127}$ Brannon, quoted Sadwave.

${ }^{128}$ Doug Coombe, "An Oral History of the Laughing Hyenas, One of the Great Unsung Detroit Rock Bands," Detroit Metro

Times, December 12, 2018.

${ }^{129}$ Callwood, "Three Chords."

${ }^{130}$ Bill Danforth, quoted in Rettman, Why Be Something, 157, 92.

${ }^{131}$ Rettman, Why Be Something, 51.

132 Ibid., 116.

133 Ibid.

134 Ibid., 68.
} 
And indeed, the community was not romantically or naively unaware of the scars of ruin that were implicit in the Freezer, the Clubhouse, or Cass Corridor, but neither were they solely fixated on them. Instead, they took great pride in their surroundings. Some years earlier, Black Flag had to leave California and start touring because local police targeted their gigs; the boys of Detroit had no such trouble: if "the cops ever rode by, which was rare, they would just stop ... [and] say ‘Wow, you guys are fuckin' stupid." 135 The musicians were drawn there not because of what the area was-the country's murder capital, "most of [it] ... burned out during the sixties riot" ${ }^{\prime 36}$ _but because of what was absent: community, pride, and care. The area was an example of what George Steinmetz, writing about Detroit, calls "negative ruins," which retain some semblance of their same pre-disaster shape but as "decontextualised bits of urban infrastructure ... [that] no longer fit together." ${ }^{137}$ It was in these "disordered, unregulated spaces of ruins" that the hardcore players found a "freedom [resisting] commodification," "138 a freedom to enact their own codes and thereby effectively negate the negativity of the ruin, making substance from its absence not by rebuilding but by embracing that very absence. The rubble was not merely inspiration for or metaphoric counterpoint to NA's music, but essential condition, an indication not of nihilistic certainty but of a "constellation defined by its afterlife," new possibilities enabled by decay. This complicated, ambivalent liminality, we might say, was the essence of the "negative approach" that the band performatively called to life for its audience.

Certainly, the case could be made that these suburban natives, mostly (but not exclusively) White and male, ${ }^{139}$ were simply "ruingazers." ${ }^{140}$ Detroit has long been a site of what can be generously termed "ruin exploration," wherein largely middle-class White men undertake "illegal but seductive" tours of the city's rubble, and perhaps less generously as "ruin porn." ${ }^{141}$ However, whether such problematic appropriative fetishization is carried out by individuals or by the mainstream media, ${ }^{142}$ the appellation necessarily implies a remove between the ruingazer and the ruin. I contend that understanding the young people of the hardcore scene in these pejorative terms ignores the degree of ownership with which they developed their community. It was not merely an "unregulated" space, but was instead linked by a de facto understanding of liminal solidarity, wherein the audience was "Ready to Fight" provided they knew the proper way to direct their aggression. In fact, many from that period believe the scene began to decline when the violence lost its ambivalent balance between community and destruction. As a new group of "skinheads," who cared more

\footnotetext{
${ }^{135}$ Azerrad, Our Band, 20; Ken Wager, quoted in Rettman, Why Be Something, 94.

136 Todd Swalla, quoted in Rettman, Why Be Something, 85.

${ }^{137}$ Steinmetz, "Harrowed Landscapes," 231.

${ }^{138}$ Apel, Beautiful Terrible Ruins, 66.

${ }^{139}$ Most notably, one of the scene's luminaries was Larissa Strickland, the founder of L-Seven, and later Brannon's girlfriend and collaborator in the band Laughing Hyenas. Further, there were often Black and queer audience members at the shows; a documented example is Ewolf, a well-known Black hardcore musician who began making music at the time, and who still lives and works in Detroit. Nevertheless, one could find other contrasts between the Midwestern and coastal hardcore scenes in terms of the latter's relatively greater diversity. For instance, The Decline of Western Civilization (a visual document that the Midwestern scene unfortunately lacks) features not only several bands fronted by or featuring female musicians or people of color, but also provides indication of several non-White or female audience members, including a female-presenting individual who memorably rushes the stage during a performance by the band Fear. There is perhaps room for a separate study that relates the concept of the ruin to the way these underrepresented members of the scene used hardcore to confront normative pressures, but that, alas, falls far outside the scope of this study.

${ }^{140}$ Steinmetz, "Harrowed Landscapes," 216.

${ }^{141}$ Apel, Beautiful Terrible Ruins, 59-60, 91-3.

${ }^{142}$ Apel, Beautiful Terrible Ruins, 77. The argument is that the discourse about Detroit is largely fed by media outlets like The New York Times which, under the guise of social service, reinforce the idea of Detroit as a wasteland through phrases like “America's first third-world city," previously quoted.
} 
about "Nazi skinhead violence" than about music, ${ }^{143}$ came to dominate the culture, the violence escalated: Brannon describes that "there was a while there where there wasn't a show that somebody didn't get seriously fucked up, like getting stabbed or getting their teeth knocked out." 144 In response, many of the bands and audiences began to abandon what they'd built, indicating that while Cass Corridor might have been a site of freedom and self-expression, it was nevertheless regulated by internal codes of solidarity and pride. Losing control of its liminal constellation of productive rubble, the scene fell apart.

There is a reason that NA's signature song is "Why Be Something That You're Not," providing the title to Tony Rettman's oral history, the aforementioned cable-access show, and even this article. Though on its surface a lambast of a poser ("Why don't you give me a fucking break? One look at you tells me you're fake" ${ }^{145}$ ), the song also functions as a committed acceptance of unstable, liminal identity, defining the community's identity precisely by what it refuses to be. As Detroit existed "at the border of city and notcity," so was the brotherhood of Cass Corridor hardcore defined by its liminality, its refusal to nail itself down. They were not actually of Detroit, but neither were they from the suburbs anymore. They embraced the catharsis of nihilistic violence, but also refused to be defined by that violence. They could care less about acceptance, and yet were desperate to be validated by their community. Like the ruins, theirs was a community both finished and unfinished, but that ambivalent liminality gave them the insight to see promise where others saw only decay, to see life where others saw death.

Audio Link: http://dx.doi.org/10.3998/mp.2340; https://youtu.be/H0dP3HyOMqo.

Example 5: Negative Approach, "Why Be Something You're Not," track 4 on Negative Approach, Touch and Go Records, 1982.

Gastón Gordillo asks what happens when "rubble is destroyed," whether such "negation of a negation" reinforces the "void" or allows the possibility of positive renewal. ${ }^{146}$ I contend that John Brannon's "negative approach" was one that begged not destruction but constructive negation, one which asks its audience even today to lean into productive negativity, to eschew platitudes of self-awareness in favor of the visceral impact of defining ourselves through the repudiation of simple binaries ("something we are" versus "something we're not”). Brannon's performativity certainly referenced the ruined surroundings of Cass Corridor, but not as a finalized endpoint, rather as a constellation that insisted his audience move forward without lamenting the shaky ground on which they must proceed. There is a dignity to that willingness to embrace tragic reality without precluding the equal potential of moving forward, a lesson that was as powerful to the Midwestern adolescents of the 1980s as it may be to us now as we continue to assess the continuing tragedy and resilience of Detroit.

\section{CONCLUSION}

Now I'm not saying

I don't have any problems

But I never run away

\footnotetext{
${ }^{143}$ Mock, “This ain't no love-in,” 207. Interestingly, their long hair first identified this group; only later did they adopt the bald affect that Brannon notes resembled the "National Front."

${ }^{144}$ Brannon, quoted in Rettman, Why Be Something, 147.

${ }^{145}$ Negative Approach, "Why Be Something You're Not," track 4 on Negative Approach, Touch and Go Records, 1982.

${ }^{146}$ Gordillo, Rubble, 119-20.
} 
I always try to solve 'em

I'll survive I'll survive

—Negative Approach, "I'll Survive"

John Brannon still spends his time around Cass Corridor. Unless he is on tour-NA reformed in 2006 for a few reunion shows (beginning with a festival curated by Sonic Youth's Thurston Moore), and Easy Action remains active-he can usually be found taking care of his mother or working as a short-order cook at the Traffic Jam \& Snug restaurant. ${ }^{147}$ Given that "he's been described as an Elvis-like figure by hardcore and punk rock aficionados," there are some who see his "humiliation [as] almost literary,"148 especially in relation to the dramatic economic resurgence of the city's downtown area where he lives. As Brannon puts it,

There are a lot of people moving to Detroit and buying these buildings and renovating them, so I've got to say it's making a comeback. We grew up in Cass Corridor, and that place has completely changed. We had the Freezer Theater and the Clubhouse back in the day, and there was nothing but dope, hookers, and pavement at that point. Now there are Thai restaurants, and yogurt places, and chicks jogging with fucking headphones on the Wayne State Campus. Back in the day, nobody was living down there. I mean, I was . . ${ }^{149}$

And he still is. He has continued to survive- the loss of his friend Larissa Strickland and their band Laughing Hyenas, an addiction to heroin - as has his city. In 2006, the same year he reformed his most famous band, new levels of investment in downtown Detroit began. Nine billion dollars have since then been committed to making the downtown feel safe again, but with little notable impact for the majority of the city whose struggle is only compounded by the continued inequity. ${ }^{150}$ For these developers, the ruin of Detroit exists as a binary: life and death, devastation and resurgence, poverty and prosperity. But for those like Brannon who continue to survive, existence demands a more complicated understanding.

Indeed, such an ambivalent understanding of the ruin, as a symbol that also surrounds the dynamic persistence of lives lived in pursuit of dignity, is a message we can read in the work Negative Approach produced in the 1980s: in their songs, in their singer's performative style, in the scene and surroundings that made all of those aesthetic expressions possible. What they offered then in their "negative approach" is a lesson we might also learn today about our understanding of Detroit as a political ruin: relying on the discourse of rubble and ruin means presuming something has been irreparably savaged, whether that is true or not.

In proudly and ambivalently trumpeting liminality over fixed ideology—better to know ourselves by knowing "something [we're] not" instead of presuming certainty-NA created work in the early 1980s that remains deeply emblematic of Detroit. A bunch of White boys were not supposed to go and play music in Cass Corridor; it was supposed to be empty and done, a gutted corpse awaiting the phoenix-powers of neoliberal reinvention. The American Dream had died, and left behind it ruins that could never be rebuilt but only reimagined by disinterested speculators. But they did. They went and played, and Brannon and his band embodied the dark reality of this place they called home, drawing attention through their pessimistic expressions to the optimistic potential that continues to survive in the "constellation" of what is left behind.

\footnotetext{
${ }^{147}$ Callwood, "Three Chords."

${ }^{148}$ Holloway, "Detroit Punks."

${ }^{149}$ Brannon, quoted in Ludwig, “"There's No Shortage."”

${ }^{150}$ Jay and Conklin, A People's History, 17-22.
} 
It may be a limited exercise to try and reduce Detroit to the story of this one band, or to use a punk group's three-year run as a means to study the limitations of ruin mythologizing, or perhaps even to use such theoretical terms for the city at all. Nevertheless, through the songs Brannon constructed, through the aggressive manner in which they were played, and through the band's brand of social rebellion, their story became a Detroit story, one that has not yet ended. Survival may be a low bar for some, but it is also not something to take for granted.

\section{Bibliography}

Apel, Dora. Beautiful Terrible Ruins: Detroit and the Anxiety of Decline. Ithaca, NY: Rutgers University Press, 2019. https://doi.org/10.36019/9780813574097-toc.

Azerrad, Michael. Our Band Could Be Your Life. New York: Little, Brown, and Co., 2002.

Callwood, Brett. "Three Chords \& the Truth.” Detroit Metro Times, June 9, 2010. https://www.metrotimes.com/detroit/three-chords-and-the-truth/Content?oid=2197541.

Cavanaugh, Jillian R. “Performativity.” In Oxford Bibliographies Online. Last modified March 10, 2015. https://doi.org/10.1093/obo/9780199766567-0114.

Chafets, Ze'ev. "The Tragedy of Detroit." The New York Times, July 29, 1990. https://www.nytimes.com/1990/07/29/magazine/the-tragedy-of-detroit.html.

Coombe, Doug. "An Oral History of the Laughing Hyenas, One of the Great Unsung Detroit Rock Bands.” Detroit Metro Times, December 12, 2018. https://www.metrotimes.com/detroit/an-oralhistory-of-the-laughing-hyenas-one-of-the-great-unsung-detroit-rockbands/Content?oid $=18664679$.

"Detroit, Michigan Population 2019 (Demographics, Maps, Graphs)." World Population Review. Accessed December 15, 2019. http://worldpopulationreview.com/us-cities/detroit-population/.

"For the first time Negative Approach interviewed by the Russian media." Sadwave, September 15, 2014. https://www.youtube.com/watch?v=lx070OhSuN8.

Gitter, Mike. "Negative Approach 2013: A Chat with Singer John Brannon.” Noisecreep, March 12, 2013. https://noisecreep.com/negative-approach-singer-john-brannon/.

Gordillo, Gastón R. Rubble: The Afterlife of Destruction. Durham: Duke University Press, 2014. https://doi.org/10.2307/j.ctv11316w0.

Griffin, John. “Tied Down—Negative Approach. All Music Guide. Accessed December 15, 2019 https://www.allmusic.com/album/tied-down-mw0000018217.

Herron, Jerry. “Borderland/Borderama/Detroit.” Places Journal(July 2010). https://doi.org/10.22269/100706.

Holloway, Zabe, dir. “Detroit Punks Episode 1: John Brannon.” July 19, 2014. https://www.youtube.com/watch?v=jFaXYsdEsGs.

Huyssen, Andreas. "Nostalgia for Ruins." Grey Room 23 (2006): 6-21. https://doi.org/10.1162/grey.2006.1.23.6.

Jay, Mark, and Philip Conklin. A People’s History of Detroit. Durham: Duke University Press, 2020. https://doi.org/10.1215/9781478009351.

Kantor, Matt. “Artist Biography of Negative Approach.” All Music Guide. Accessed December 15, 2019. https://www.allmusic.com/artist/negative-approach-mn0000386253/biography. 
—_. "Total Recall-Negative Approach." All Music Guide. Accessed December 15, 2019. https://www.allmusic.com/album/total-recall-mw0000086382.

Katel, Jacob. “Negative Approach: You Can't Kill Hardcore.” Miami New Times, October 21, 2013. https://www.miaminewtimes.com/music/negative-approach-you-cant-kill-hardcore-6472698.

Kramer, Richard. "The Hedgehog: Of Fragments Finished and Unfinished." 19th-Century Music 21, no. 2 (1997): 134-48. https://doi.org/10.1525/ncm.1997.21.2.02a00020.

Ludwig, Jamie. “There's No Shortage of Blood and Crazy Motherfuckers': An Interview with John Brannon of Negative Approach.” Vice (blog), December 9, 2013. https://www.vice.com/en us/article/rzgnj6/theres-no-shortage-of-blood-and-crazy-motherfuckersan-interview-with-john-brannon-of-negative-approach.

Maraniss, David. Once in a Great City: A Detroit Story. New York: Simon \& Schuster, 2015.

Miller, Steve. “An Oral History of Detroit Punk Rock.” Longreads, November 18, 2018. https://longreads.com/2018/11/19/an-oral-history-of-detroit-punk-rock/.

Mock, Roberta. “This ain't no love-in, this ain't no happenin': Misfits, Detroit hardcore and the performance of zombie scenarios." Studies in Theatre and Performance 34, no. 3 (2014): 201-10. https://doi.org/10.1080/14682761.2014.961363.

Negative Approach. Negative Approach. Touch and Go Records, 1982.

- Nothing Will Stand in Our Way. Taang! Records, 2011.

—. Tied Down. Touch and Go Records, 1983.

"Negative Approach." Interview with John Brannon. Punk News for Punx!, MPRV News. August 14, 2018. https://www.youtube.com/watch?v=QMOpaUkU818.

Osborn, Brad. "Subverting the Verse-Chorus Paradigm: Terminally Climactic Forms in Recent Rock Music." Music Theory Spectrum 35, no. 1 (2013): 23-47. https://doi.org/10.1525/mts.2013.35.1.23.

Rettman, Tony. Why Be Something That You're Not: Detroit Hardcore 1979-1985. Huntington Beach, CA: Revelation Records, 2010.

Spheeris, Penelope, dir. The Decline of Western Civilization. Atlantic Television, 1981.

Steinmetz, George. "Harrowed Landscapes: White Ruingazers in Namibia and Detroit and the Cultivation of Memory." Visual Studies 23, no. 3 (2008): 211-37. https://doi.org/10.1080/14725860802489890.

Sugrue, Thomas J. The Origins of the Urban Crisis: Race and Inequality in Postwar Detroit. Princeton, NJ: Princeton University Press, 1996.

"Why Be Something You're Not.” Cable Access Show. Detroit, MI. 1982. Accessed December 14, 2019. https://www.youtube.com/watch?v=ms41upbshtc.

Wollman, Elizabeth L. The Theater Will Rock: A History of the Rock Musical: From Hair to Hedwig. Ann Arbor: University of Michigan Press, 2006. https://doi.org/10.3998/mpub.119496. 